\title{
Penguasaan Keterampilan Tata Rias Pengantin Modifikasi bagi Anggota Karangtaruna Melalui Pelatihan dengan Hand Out
}

\author{
Maspiyah $^{1}$, Nia Kustianti ${ }^{1}$, BiyanYesi Wilujeng \\ ${ }^{1}$ Dosen Universitas Negeri Surabaya \\ Email: maspiyah@unesa.ac.id
}

\begin{abstract}
Abstrak. Tujuan penelitian ini adalah untuk mengetahui 1) penguasaan keterampilan peserta pelatihan dalam merias pengantin modifikasi bagi karangtaruna Kelurahan Magersari KabupatenSidoarjo, dan 2) respon peserta pelatihan dalam merias pengantin modifikasi bagi karangtaruna Kelurahan Magersari Kabupaten Sidoarjo. Jenis penelitian ini adalah preeksperimen, dengan menggunakan desain one shot case study. Jumlah peserta pelatihan sebanyak 20 orang. Metode pengumpulan data yang digunakan adalah tes praktik, dan angket. Teknik analisis data yang digunakan adalah persentase untuk mengetahuan hasil keterampilan, serta nilai rata-rata (mean) untuk mengetahui respon peserta pelatihan. Hasil pelatihan menunjukkan 1) nilai keterampilan 75-84 sebanyak 15\%, nilai 85-94 sebanyak 85\%. 2) respon peserta merasa senang mengikuti pelatihan sebanyak $90 \%$, peserta mudah mendapatkan alat dan bahan pelatihan sebanyak $85 \%$, biaya terjangkau sebanyak $85 \%$, penyampaian materi jelas dan mudah dipraktikkan sebanyak 90\%, penggunaan hand out membantu memahami materi sebanyak 95\%, dan hand out yang digunakan mudah difahami sebanyak 95\%.
\end{abstract}

\section{Kata Kunci: Keterampilan,Tata Rias Pengantin Modifikasi}

\section{PENDAHULUAN}

Tata rias wajah merupakan suatu bentuk tindakan yang memiliki tujuan mempercantik wajah. Prinsip tata rias ini adalah menutupi kekurangan dan menonjolkan kelebihan pada wajah. Menurut Kusantati (2009), bentuk wajah merupakan salah satu faktor penting yang perlu diperhatikan dalam tata rias wajah, karena setiap orang memiliki bentuk wajah yang berbeda dan unik.Secara umum terdapat beberapa tipe bentuk wajah, bentuk wajah ditentukan oleh kedudukan dan menonjolkan tulang-tulang wajah.
Tidak semua wajar mempunyai bentuk yang sempurna sehingga diperlukan koreksi wajah ketika hendak meriasnya. Untuk mengoreksi hal tersebut maka perlu adanya pengetahuan tentang tata rias wajah korektif yang bertujuan dari rias untuk mendapatkan hasil kecantikan yang seketika dan lebih bersifat psikologis (Santosa, 2009)

Tata rias wajah korektif diperlukan atas prinsip dasar bahwa bentuk wajah yang dianggap kurang sempurna dapat diubah sedemikian rupa, sehingga penampilannya menjadi lebih baik. Untuk tujuan ini, bagian- 
bagian wajah tertentu diberi warna gelap (shade), dan ada pula yang diberi warna terang (tint, highlighting). Jadi tata rias koreksi wajah adalah menonjolkan bagian wajah yang indah dan menutupi bagian wajah yang kurang sempurna. Untuk mempelajari semua hal di atas baik untuk penataan hijab maupun tata rias wajah korektif perlu adanya tentor yang menjelaskan dan memberikan informasi tersebut. Hal ini dapat kita latih dengan mengasah keterampilan mereka dalam merias wajah dan penataan hijab pesta. Sedangkan tata rias pengantin merupakan tata rias yang digunakan pada saat seseorang menjalankan pesta pernikahan (Rusman, 2012)

Keterampilan dan kreativitas merupakan salah satu faktor penunjang untuk membuka usaha atau bisnis yang membuka usaha atau bisnis yang menjadikan seseorang bisa mandiri tanpa bergantung kepada pekerjaan yang diberikan oleh orang lain. Selain itu kreativitas juga merupakan bekal utama dalam memasuki dunia industri. Selain pada pendidikan formal, keterampilan juga dapat diasah melalui pendidikan nonformal yaitu pendidikan keterampilan dan pelatihan kerja, pendidikan pemberdayaan perempuan, pendidikan yang dilaksanaakan dilembaga kursus, pelatihan kelompok belajar, pelatihan pada organisasi misalnya karangtaruna, serta satuan pendidikan lain yang sejenis, melalui pendidikan formal yang biasa dilaksanakan pada lembaga-lembaga pendidikan baik sekolah maupun kelompok kerja (Direktorat, 2009).

Dengan latar masalah tersebut, menginspirasi penulis untuk memberikan pelatihan yang dapat mengasah keterampilan anggota karangtaruna dengan memberikan pelatihan tata rias pengantin modifikasi. Tujuan pelatihan ini untuk mengetahui 1) hasil pelatihan tata rias pengantin modifikasi pada anggota karangtaruna Kelurahan Magersari Kecamatan Sidoarjo Kabupaten Sidoarjo, dan 2) respon peserta pelatihan tata rias pengantin modifikasi Kelurahan Magersari Kabupaten Sidoarjo.

\section{METODE PENELITIAN}

Ini adalah pre-eksperimen, dengan menggunakan desain one shot case study terhadap peserta pelatihan sebanyak 20 orang. Data tes praktek dikumpulkan menggunakan angket. Prosedur penelitian adalah sebagai berikut:

1. Merumuskan masalah

2. Menentukan metode kegiatan yaitu: metode pelatihan dan pendampingan 
3. Pembentukan kelompok. Membentuk 5 kelompok@ 4 orang

4. Persiapan pelaksanaan pelatihan. Dalam kegiatan ini pihak mitra diberikan bantuan peralatan penunjang berupa 5 set kosmetik dekoratif, 5 set kuas make-up, 5 set hair piece, 5 set jilbab pengantin dan asesoris, 5 buah sisir berekor, 5 buah sisir sasak, dan 5 tabung hairspray.

5. Pelatihan ketrampilan jasa tata rias pengantin. Tujuan pelatihan adalah untuk melatih ketrampilan tata rias wajah sanggul dan penataan rambut, perawatan wajah, dan penataan jilbab.

6. Tes akhir.

Teknik analisis data yang digunakan adalah persentase untuk mengetahuan hasil keterampilan, serta nilai rata-rata (mean) untuk mengetahui respon peserta pelatihan.

\section{HASIL DAN PEMBAHASAN}

Kegiatan ini dapat berjalan dengan baik dan lancar. Adapun jabaran dari hasil kegiatan adalah sebagai berikut:

\section{Penilaian Partisipasi}

Penilaian partisipasi kehadiran peserta, dilihat dari data kehadiran. Semua peserta (100\%) hadir, tertib dan antusias dalam mengikuti tahapan kegiatan hingga selesai. Keaktifan peserta pelatihan ditunjukkan dari kegiatan bertanya, menjawab pertanyaan instruktur, mengajukan pendapat saat berlangsung teori dan praktek, peran serta dalam kegiatan praktek. Partisipasi keaktivan dari peserta pelatihan tergolong cukup baik.

2. Hasil pelatihan Merias Pengantin

Setiap peserta mengerjakakan keterampilan merias wajah, merias rambut atau memakai jilbab. Alat dan bahan yang digunakan yaitu kuas make-up, sanggul, jilbab telah disiapkan oleh instruktur, sedangkan model disiapkan oleh peserta yaitu secara berpasanngan atau bergantia. Hasil penilaian produk rias jasa pengantin selama kegiatan praktik adalah sebagai berikut:

a. Keterampilan Merias Wajah Pengantin

1) Hasil akhir pengaplikasian foundation tergolong baik. Hal ini terlihat dari hasil jadi yang telah dikerjakan oleh peserta pelatihan $85 \%$ baik.

2) Hasil akhir pengaplikasian highlight juga tergolong baik yang terlihat dari hasil jadi yang telah dikerjakan oleh peserta pelatihan $80 \%$ baik.

3) Hasil akhir pengaplikasian shadding adalah baik. Hal ini terlihat dari hasil jadi yang telah dikerjakan oleh peserta pelatihan $80 \%$ baik. 


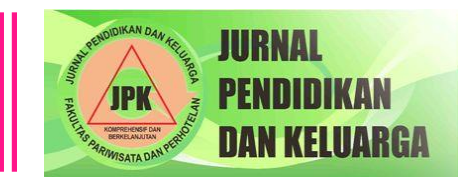

4) Hasil akhir pengaplikasian bedak. Hal ini terlihat dari hasil jadi yang telah dikerjakan oleh peserta pelatihan $85 \%$ baik.

5) Hasil akhir pengaplikasian eye shadow tergolong baik. Hal ini terlihat dari hasil jadi yang telah dikerjakan oleh peserta pelatihan $80 \%$ baik.

6) Hasil akhir pengaplikasian eyeliner dan mascara adalah baik yang terlihat dari hasil jadi yang telah dikerjakan oleh peserta pelatihan $86 \%$ baik.

7) Hasil akhir pengaplikasian pembuatan alis adalah baik. Hal ini terlihat dari hasil jadi yang telah dikerjakan oleh peserta pelatihan $80 \%$ baik.

8) Hasil akhir pengaplikasian blush-on pada umumnya (82\%) baik.

9) Hasil akhir pengaplikasian koreksi lipstick pada umumnya (90\%) baik.

10) Hasil akhir riasan wajah secara keseluruhan. Penilaiannnya meliputi teknik pengaplikasian yang halusdanrapi sesuai dengan koreksi bentuk wajah, pengaplikasian highlight merata pada bagian yang diberi highlight untuk memberi kesan tirus. Hal ini terlihat dari hasil jadi yang telah dikerjakan oleh peserta pelatihan $82 \%$ baik.

b. Keterampilan Penataan Rambut

1) Penataan rambut sesuai dengan bentuk wajah $76 \%$ baik

2) Kreativitas dalam penataan rambut $78 \%$ baik.

3) Kerapian dalam penataaan rambut $80 \%$ baik.

4) Hasil akhir secara keseluruhan penataan rambut $78 \%$ baik.

c. Penataan Hijab Pengantin

1) Sesuai dengan bentuk wajah $80 \%$ baik.

2) Kreativitas $82 \%$ baik

3) Kerapian $78 \%$ baik.

4) Hasil akhir secara keseluruhan penataan hijab $80 \%$ baik

\section{Tanggapan Pelatihan}

Pada umumnya $(80 \%)$ peserta menyatakan bahwa pelatihan ini bermanfaat. Motivasi yang tinggi antara lain disebabkan karena metode pelatihan praktek adalah partisipasi langsung. Metode ini memberikan kepuasan tersendiri bagi peserta. Sealain itu produk yang dilatihkan dibutuhkan, dan mampunyai nilai komersial. 


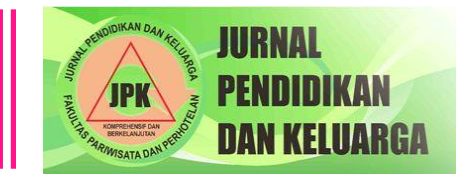

\section{KESIMPULAN DAN SARAN}

Kesimpulan

1. Pelaksanaan kegiatan pelatihan keterampilan merias pengantin yang meliputi rias wajah, rias rambut, dan jilbab berjalan lancar. Peserta sebagian besar aktif, mempunyai motivasi tinggi, hal ini dapat dilihat dari kehadiran peserta.

2. Melalui kegiatan ini, peserta merasakan manfaat yang positif. Peserta merasa mendapat tambahan ketrampilan sebagai peluang untuk melakukan usaha jasa perias penganin.

Saran

1. Pelaksanaan kegiatan pelatihan keterampilan merias pengantin ini membutuhkan ketrampilan yang lebih tinggi. Untuk itu bisa juga dibuat kelompok. Yang sudah trampil diberi model yang agak rumit, sedangkan yang masih tahap belajar diberi model yang lebih mudah.

2. Keterampilan tata rias ini bisa diterapkan untuk berbagai kesempatan, misal merias untuk karval, wisuda, pesta, dan lain-lain.

\section{DAFTAR PUSTAKA}

Direktorat Pembinaan Kursus dan Kelembagaan. 2009. Tata Rias Pengantin Tanpa Paes. Jakarta: Departemen Pendidikan Nasional.

Hidayah, N dan Maspiyah, 2014 .Penerapan Fungsi Manajemen pada Devisi Rias untuk Pelayanan Jasa Pengantin di Adji Wedding Gallery. Surabaya, Jurnal online Unesa. Vol.2 NO. 04

Kusantati, Herni ; Prihatin, Pipin Tresna dan Wiana, Winwin. 2008. Tata Kecantikan Jilid 3. Jakarta: Direktorat Jenderal Pendidikan Dasar dan Menengah, Departemen Pendidikan Nasional.

Kyin, Robert. 2006. Study Kasus Desain dan Metode, Jakarta: PT. Raja Garafmdo Persada

Rostamailis, dkk. 2008. Tata kecantikan Rambut Jilid 1. Jakarta: Direktorat Pembinaan Sekolah Menengah Kejuruan, Direktorat Jenderal Manajemen Pendidikan Dasar dan Menengah, Departemen Pendidikan Nasional.

Rusman, E, 2012, Tata Rias Pengantin Modifikasi Daerah Jawa Timur, Makalah, Tidak diterbitkan. Osa, Tien, 2009. Tata Rias dan Busana Seluruh Indonesia, Jakarta: Gramedia Pustaka Utama 